\title{
The Effect of Macroeconomic Variables on the Asset Positions and Financial Performance of Non-Banking Financial Institutions (NBFIs) in Jamaica
}

\section{Floyd Thompson*}

Research and Policy Division, Financial Services Commission, Kingston, Jamaica

Email: floyd.t.thompson@gmail.com

How to cite this paper: Thompson, F. (2021). The Effect of Macroeconomic Variables on the Asset Positions and Financial Performance of Non-Banking Financial Institutions (NBFIs) in Jamaica. Open Journal of Business and Management, 9, 1424-1445.

https://doi.org/10.4236/ojbm.2021.93076

Received: March 31, 2021

Accepted: May 28, 2021

Published: May 31, 2021

Copyright $\odot 2021$ by author(s) and Scientific Research Publishing Inc. This work is licensed under the Creative Commons Attribution International License (CC BY 4.0).

http://creativecommons.org/licenses/by/4.0/ (c) (i) Open Access

\begin{abstract}
The aim of the paper is to evaluate the effect of macroeconomic variables such as real GDP, unemployment levels, bond yields, stock market growth, and interest rate on the asset positions and financial performance of non-banking financial institutions (NBFIs) in Jamaica. This is reflected by return on asset (ROA) ratio, return on equity (ROE) ratio and total asset growth (TA). To explore the nature of the short and long-term relationship between dependent variables and independent variables, the research used a bound test approach to the co-integration and error correction process using time series data over the period from 2005Q1 to 2020Q3. The results showed that real gross domestic product (RGDP) and unemployment rate (UR) had a positive long-run relationship with ROA; government bond yield (GBY), UR, interest rate (IR) and stock market growth (JSEM) influenced ROE positively at the long-run; while all the independent variables showed a long-run causal relationship with TA. In the short-run estimates, however, minimal short-run causal relationships among variables could be identified with ROA, ROE and TA. Meanwhile, the research has shown there is a stable long-run relationship between the three profitability metrics and the variables that have a significant long-run relationship with them. This assumes that, in the event of some shock to the system, the model will converge back to equilibrium. Furthermore, the cumulative sum of recursive residuals (CUSUM) checks validated the model's stability.
\end{abstract}

\section{Keywords}

Financial Performance, Macroeconomy, ARDL Model, Unit Root

${ }^{\star}$ The views expressed in this paper are those of the author and do not necessarily reflect the views of the Financial Services Commission. 


\section{Introduction}

In the age of globalization, the threat of competition made many businesses more mindful of the value of financial performance. It is clear that the performance of companies is influenced by both internal and external factors. Specifically, internal factors relate to the capacity of firms to gain efficiency and minimize costs whereas the state of the economy, government policy, exchange rate, GDP, unemployment rate, and others, are often perceived to be key components that influence the business from an external point of view.

NBFIs are subtly different and have different phenomena from banking institutions. These NBFIs offer services that are not specifically designed for banks and are uniquely built for various industries. Even though banks provide a range of financial services, NBFIs customise their services to suit the particular needs of diverse groups through alternative financial services, such as contractual savings, credit facilities, money market trading, stock and bond purchases as well as private education and retirement plans. Additionally, NBFIs aid in the rotation of capital, the allocation of assets and the management of profits to influence economic development by improving the job sector and boosting financial markets, resulting in the growth of Jamaica's gross domestic product (GDP). A multi-faceted financial system, including NBFIs, will safeguard and recover economies from financial shocks. NBFIs provide a range of options for converting and channelling surplus units into profitable economic investment practices that help satisfy the credit demand by individuals and companies that banks are unable to supply. Undoubtedly, well-functioning financial institutions play a significant role in economic development and financial performance (Rabaa \& Younes, 2016). In brief, Jamaica's financial system today is more mature, robust, and better developed, which plays a key role in accelerating the stable growth of Jamaican economy.

The Jamaican NBFI sector, comprising mainly of securities dealers, insurance companies and pension funds, has seen considerable growth and transition in recent years with economic progress, as seen by the significant growth of its total assets since 2005. In September 2020, the total assets of NBFIs amounted to $\$ 1.82$ trillion, more than four times the total assets of $\$ 411.7$ billion in March 2005. By September 2020, the assets of NBFIs accounted for almost half (46 per cent) of the total assets of Jamaica's financial sector ${ }^{1}$ and rose by 4 per cent since March 2005. Major systemic shifts, mergers and acquisitions, fintech innovations, financial access and inclusion, regulatory reforms and deregulation of the banking industry have coincided with this phase of rapid growth in the NBFI market, thereby encouraging NBFIs to compete in the financial services industry.

It has also been strongly reiterated by recent crises that a recession will inflict costs on the broader economy in all or part of the NBFI market. It is critical that

${ }^{1}$ Jamaica's financial sector includes 8 Commercial Banks, 1 Merchant Bank, 2 Building Societies, 25 Credit Unions, 7 Life Insurance, 11 Non-Life Insurance companies, 32 Securities Dealers and 817 Pension Funds. 
attempts to ensure the solvency of NBFIs include the detection of vulnerabilities concerning the profitability of NBFIs since this is the first line of protection against unforeseen losses that can potentially erode the overall financial system. Profits, however, are a reliable early-warning predictor of financial hardship. Banks and NBFIs engage closely with current global financial and monetary policies, which can lead to sustainable development in general and as such, policymakers need to consider the potential impact of their policies on these entities. It is therefore important for policymakers to research the different economic fluctuations and indicators that impact the sustainability of NBFIs. Otherwise, the actions of NBFIs will lead to unsustainable growth of the economy, and all of the consequences that entail. This is because financial markets are internationally interlinked and how they play their function will influence the economy. As a result, several early studies on bank performance centred primarily on exploring the determinants of bank profitability. In addition, the profitability of the banking sector stimulates the growth of the economy to mitigate negative shocks, as indicated by the studies of Bikker and Hu (2002) and Demirguc-Kunt and Huizinga (1999), which showed a positive relationship between economic growth (GDP) and bank performance.

Prior literature in Jamaica also focused on studying the determinants of the various components of the profitability of banks, in particular the net interest margins concerning the duopolistic structure of the banking sector in Jamaica. There is a void, however, concerning the profitability of the NBFIs within the framework of the Jamaican economy. This research will concentrate on macroeconomic metrics and their effect on the asset positions and the financial performance of NBFIs in Jamaica. The key goal of the study of macroeconomic policy is to achieve complexity and to forecast the risks of financial and economic decision-making processes (Islatince, 2015). To fill the research void, the study adopted the normal macroeconomic indicators as independent variables such as real gross domestic product, bond yields, interest rate, stock market growth and unemployment rate while the sustainable profitability performance of NBFIs will be measured, as a dependent variable, including the rate of return on assets, the rate of return on equity and total asset growth.

The research paper is formatted as follows: Section 2 presents the literature on the profitability determinants of NBFIs, Section 3 explains the macroeconomic trends in Jamaica, Section 4 includes an overview of the data used in the analysis and the empirical model, Section 5 presents the results of the study, analyses and presentations of the data. In addition, Section 6 describes the results of the report along with policy recommendations.

\section{Literature Review}

Based on the literature, this study seeks to further analyse the known relationship between the performance of NBFIs' and macroeconomic variables.

To gain insight into the impact of macro variables on financial performance 
and asset growth, numerous studies have been undertaken. Most of these studies, however, concentrated on commercial banks, and only a limited number are focused on non-bank financial institutions. This may be because the banking industry is more mature.

Over the period 1985 to 2001, Athanasoglou et al. (2008) applied a Generalized Method of Moment (GMM) technique to a panel of Greek bank data. The results showcased that inflation and cyclical output positively affected banks' profitability as well as performance. Additionally, Kosmidou et al. (2008) studied 32 business banks in the UK over the period 1995 to 2002. The study showed that inflation-related macroeconomic factors such as GDP, inflation, market interest rates and ownership had a positive effect on the profitability of the banks, expressed in their ROA and NIM (Net Interest Margin).

Vong and Chan (2009) analysed the effect of bank characteristics as well as the macro-economic and financial structure variables on the performance of the Macau banking industry. The outcome revealed that there was a strong correlation between the rate of inflation and the performance of banks. Additionally, by using data from the top 15 Pakistani commercial banks over the 2005-2009 period, Gul et al. (2011) analysed the effect of bank-specific and macroeconomic features on bank profitability. A pool ordinary least square was used to explore the effect of assets, loans, equity, deposits, economic development, inflation and market capitalisation on major profitability metrics: (ROA), (ROE), Return on capital employed (ROCE) and (NIM). The results have shown strong evidence that both internal and external influences have a strong impact on profitability.

The Alper and Anbar (2011) research, "Macroeconomic profitability determinants of commercial banks in Turkey", used annual data over the period 2002 to 2010. The profitability of commercial banks was expressed by the dependent variables, including the (ROA) and (ROE). Macroeconomic determinants were represented by independent variables such as real interest rates, inflation and GDP. The outcome of the analysis is that, with the exception of real interest rate, macroeconomic variables had little influence, which has had a major and positive impact on the profitability of commercial banks in Turkey.

Similarly, for the years 2001-2011, Kanwal and Nadeem (2013) examined the impact of external factors on the profitability of limited public commercial banks in Pakistan. The findings revealed that a clear beneficial association existed between the real interest rate and the ROA and the equity multiplier (EM). Secondly, real GDP had a marginally positive effect on the ROA but had an adverse effect on the ROE and EM. On the other hand, inflation was seen to have a negative effect on the profitability indicators. Overall, the selected macroeconomic variables have been shown to have a marginal effect on the profitability of commercial banks.

Bilal et al. (2013) assessed the effect of specific bank and macro-economic factors such as inflation, and GDP on the profitability of commercial banks in Pakistan between 2007 and 2011. The research observed that inflation had a 
negative effect on return on asset, while real GDP had a positive impact on ROA. The capital ratio has a major positive effect on ROE.

In a paper, Pan Q. and Pan M. (2014) examined the possible effect of external factors on ten (10) Chinese banks' profitability between 1998-2012. Based on correlation and regression analysis, the findings showed that GDP, inflation, interest rates and growth in the supply of money had a positive association with bank profitability, while the aggregate capitalization of the stock market was negatively correlated with banks' profitability.

Another investigation looked at the impact of macro-economic conditions on the financial viability of ten (10) listed commercial banks in the Nairobi Securities Exchange (NSE) between 2001 and 2012. Random Effect Model and Fixed Effects Model were used as a statistical instrument with GDP, Exchange Rate and Interest Rate as independent variables and ROA as dependent variables. The study showed that real GDP growth rate had a positive but negligible effect; real interest rates had a substantial negative impact on profitability and the exchange rate had a positive impact on the profitability of listed commercial banks on the Nairobi Securities Exchange (Simiyu \& Ngile, 2015).

In addition, another report discussed the macro-economic determinants and their relationship to the profitability of commercial banks in Namibia, as well as the study, adopted unit root analysis and error variance analysis techniques in the key data for the period from 2001 to 2014 . The analysis demonstrated that all macroeconomic factors, including GDP, inflation and interest rates, had no positive influence on the profitability of commercial banks operating in Namibia at any rate (Johannes, 2015).

Similarly, the literature shows that the linkages between NBFIs' performance and macroeconomic factors can be both direct and indirect. Bangladesh Bank's Financial Stability Report (2010) indicated an improvement in the ROA and ROE ratios of the NBFIs from 2006 to 2010, which it concluded were as a result of increased use of assets and equity. Moreover, the decomposition of the sources of overall profits showed that the dominant share is due to interest income.

According to Siddiqui (2012) in her paper, "Capital Structure Determinants of Non-Bank Financial Institutions (NBFIs) in Bangladesh", attempted to create a relationship between capital structure decisions and several parameters, including profitability, liquidity, operating leverage, growth rate, and business size. The author used long-term debt ratios, short-term debt ratios and total debt ratios as dependent variables and the results revealed that the long-term debt ratio and the short-term debt ratio were not important in terms of profitability in all three situations. This challenged the theory that profitability has a detrimental association with long-term and overall debt ratios. Although the outcome was not statistically important, the study found that profitability had a negative association with short-term debt that complies with the hypothesis of Siddiqui's paper. Another researcher, Mazumder (2015), in investigating the effect of specified profitability metrics on net profit, examined six (6) NBFIs. The findings revealed 
that independent variables such as total assets and total equity had a direct impact on NBFIs profitability in Bangladesh.

Aihie and Eburajolo (2018) investigated the impact of macroeconomic factors on the development of finance houses in Nigeria using stepwise econometric equations. The results indicated that there is a major positive relationship between GDP and the growth of total assets of finance houses within the short term, however, this diminishes after a two-year lag and in subsequent years. Another research showed that the relationship between real GDP per capita and NBFIs is more favourable in the longterm (Islam \& Osman, 2011).

The financial fragility of banks and insurance firms was predicted by Bernoth and Pick (2009) using a panel data collection of performance indicators. This study found that, when evaluating and forecasting their fragility, financial linkages between banks and insurance companies are significant. The study also found that in explaining the success of banks and insurance firms, a variety of macroeconomic variables and unobserved factors are significant.

From the literature reviewed, much of the analyses used Augmented Dickey-Fuller (ADF) tests to measure the variable's stationarity properties, although, according to Zivot and Andrews (1992) who claimed that there was a structural break, the ADF may be inefficient in evaluating the root unit of a variable. In light of this, the study used the ADF and the Zivot Andrew test to evaluate the unit root of the variables to ensure that the variables were sufficient for our estimation. In addition, the Auto Regressive Distributive Lags (ARDL) method developed by Pesaran et al. (2001) was adapted for the research.

\section{Macroeconomic Trends in Jamaica}

For the period under review (Q1 2005 TO Q4 2020) real GDP showed cyclical fluctuations. The lowest figure in this cycle was a noticeable reduction of $-15.80 \%$ in real GDP (RGDP) in Q2 2020 which was immediately followed by a 6.25\% growth in Q3 2020. The $-15.80 \%$ reduction in RGDP was due to the economic shock caused by the coronavirus (COVID-19) pandemic as curfews and travel restrictions placed a strain on trade, tourism and the local economy in general. Interestingly, the 2007-2008 Global Financial Crisis (GFC) had no significant impact on RGDP as there was no notable contraction in the RGDP cycle during that period. This insignificant impact may be attributed to the GFC mainly affecting the balance sheets of investment banks with collateralised debt obligations and mortgage-backed securities.

\section{RGDP vs ROE, ROA \& TA}

Based on preliminary correlation tests, ROE, ROA and TA have correlations of $15.46 \%, 33.20 \%$ and $-19.87 \%$ with RGDP respectively. In Figure 1, positive correlations for ROE and ROA are expected as these measures theoretically tend to show some amount of procyclicality with GDP (ROE/ROA are high when the economy is good and low when it is bad). The weak negative correlation of RGDP with TA is mainly attributed to increases in assets in times of economic 
contraction (See Figure 2). This is apparent in Q3 2008 where the economy contracted by $-3.16 \%$ and TA grew by its highest of the entire period $33.40 \%$.

The unemployment rate (UR) for the period under review averaged $11.39 \%$. From Q4 2005 to Q1 2013, UR experienced a general upward trend moving from $12.1 \%$ in Q4 2005 to $16.3 \%$ (the highest rate of unemployment during the entire review period) in Q1 2013. The period Q1 2013 to Q2 2020 is characterised by a downwards trend in unemployment where the rate was reduced to $7.3 \%$ in Q2 2020 from the 16.3\% high in Q1 2013. Q3 2020 saw a sharp spike in the UR to $12.6 \%$ which was $5.3 \%$ higher than the previous quarter. This spike resulted from a fall in unemployment especially in the tourism and hospitality sector caused by the COVID-19 pandemic.

\section{UR vs ROE, ROA \& TA}

Preliminary correlation calculations illustrated that ROE, ROA and TA are all negatively correlated with UR with correlations of $-18.78,-5.12 \%$ and $-13.79 \%$

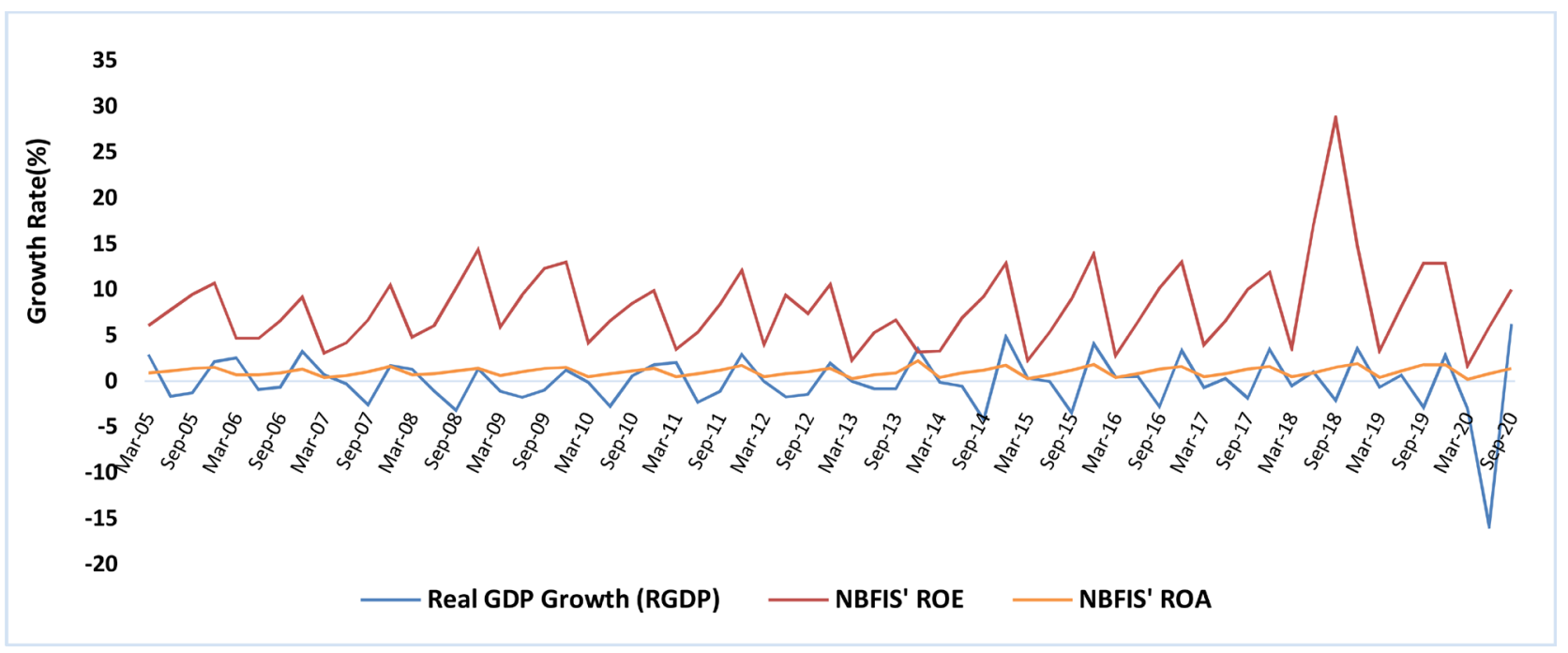

Figure 1. Trend in NBFIs' ROE, ROA and RGDP.

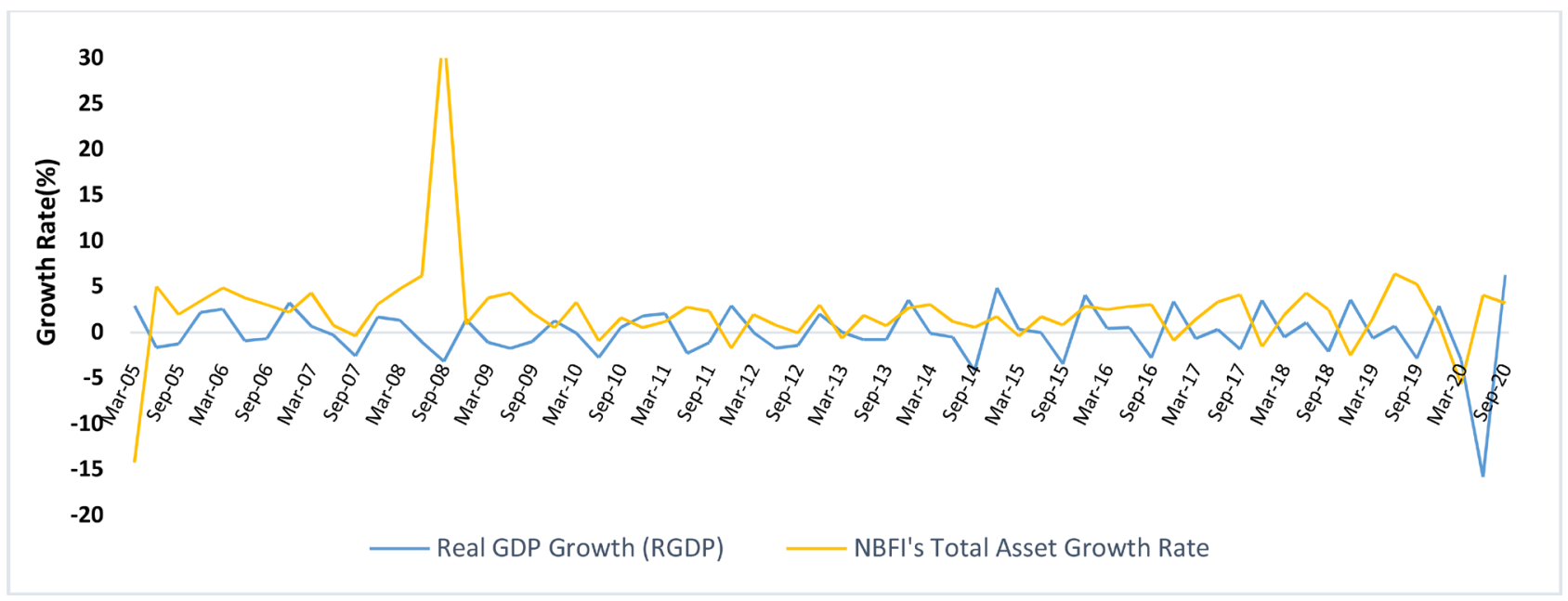

Figure 2. RGDP and TA. 


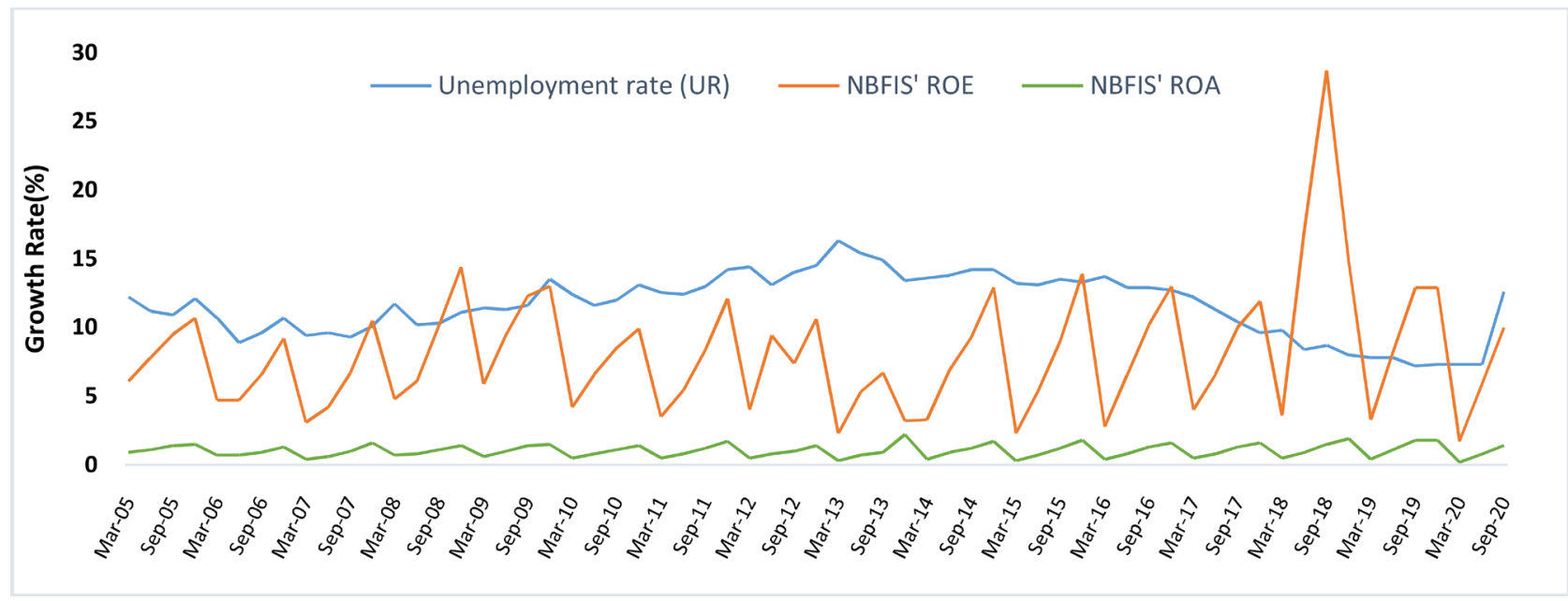

Figure 3. UR, ROA and ROE.

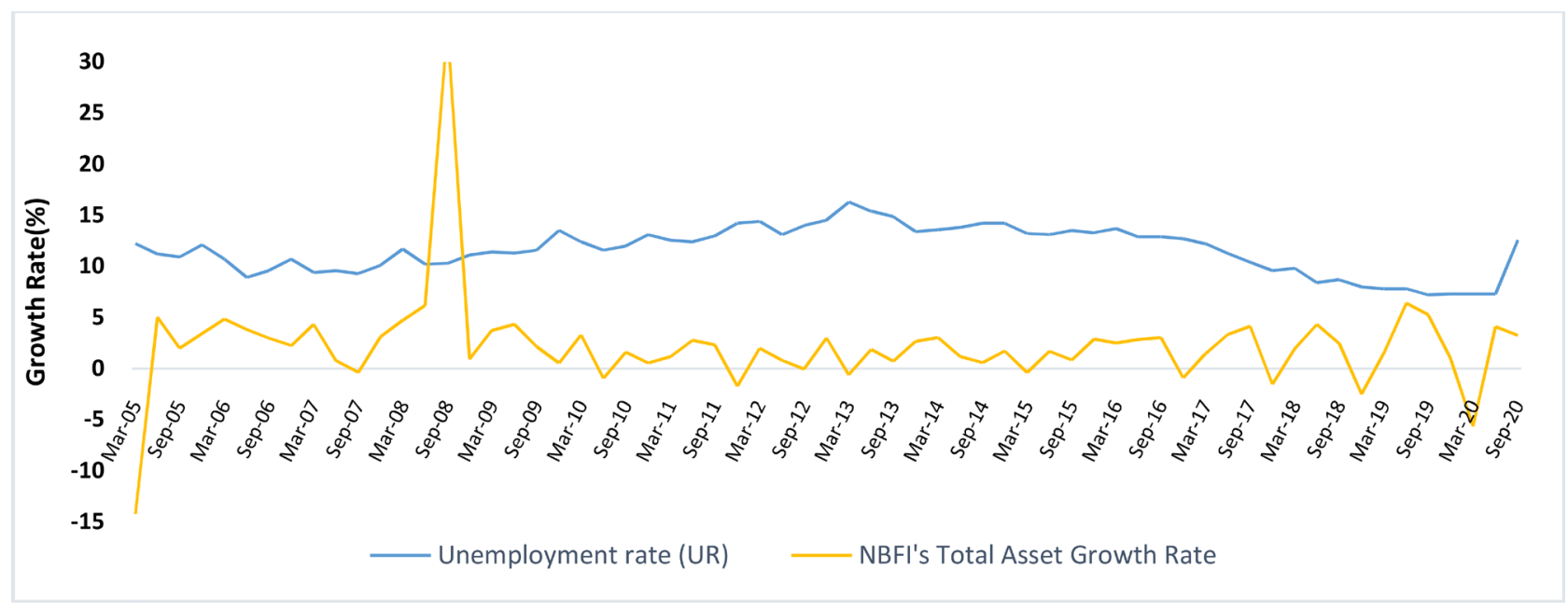

Figure 4. UR and TA.

respectively (See Figure 3 \& Figure 4). ROA was very weekly correlated with UR.

The 180-day Treasury Bills rate (IR) recorded its highest rates in the years leading up to and immediately following the GFC with the interest rate reaching its peak of $23.05 \%$ in Q1 2009. Thereafter, the interest rate was sharply reduced to its lowest level of $1.41 \%$.

\section{IR vs ROE, ROA \& TA}

Based on the preliminary correlation tests in Figure 5, both ROE and ROA showed weak negative correlations with IR with figures of $-9.04 \%$ and $-4.99 \%$ respectively. While in Figure 6, a positive correlation of $17.19 \%$ between TA and IR was observed over the review period.

Jamaica Stock Exchange Main index (JSEM) growth rate fluctuated around a mean of 2.50 with a standard deviation of 11.06. The highest JSE return for the period reviewed was recorded in Q4 2015 where the return reached a peak of 56.4. As expected, the lowest returns were the -24.78 recorded Q4 2008 and the 


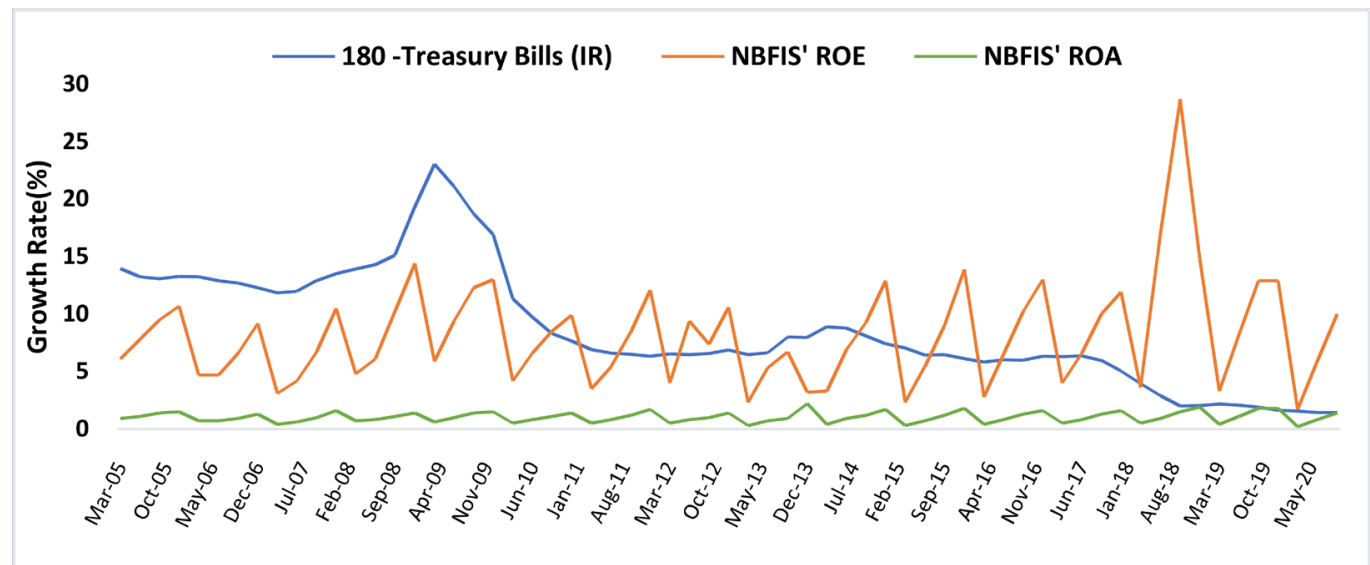

Figure 5. IR, ROA and ROE.

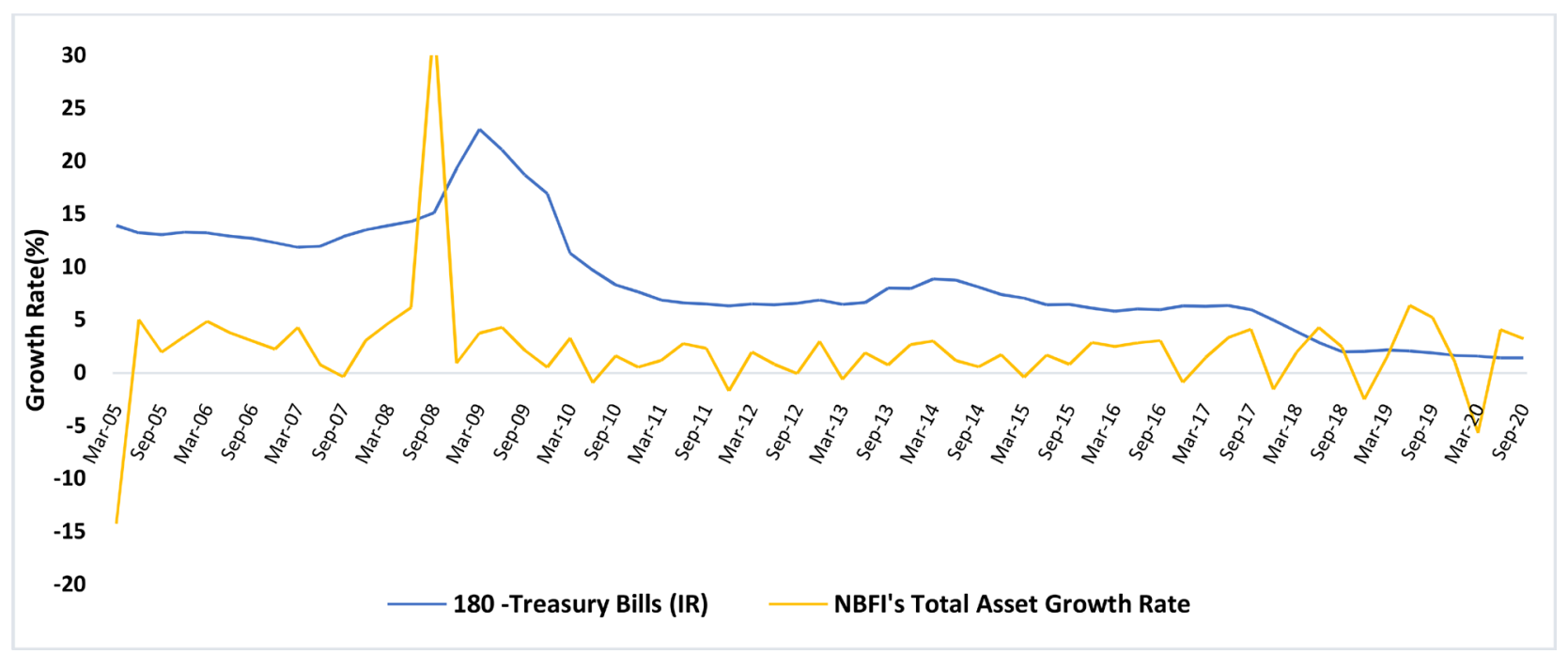

Figure 6. IR and TA.

-25.78 reported in Q1 2020, these periods correlate with the GFC and the coronavirus pandemic respectively.

JSEM vs ROE, ROA \& TA

The JSEM growth rate showed a moderately strong preliminary positive correlation of $33.40 \%$ and $32.43 \%$ with ROE and ROA (See Figure 7). However, weak positive correlation of $0.41 \%$ was displayed with TA (See Figure 8).

\section{Empirical Model}

\subsection{Data and Method}

The types of data and variables used in this analysis will be discussed in this section. Furthermore, the method of estimation used to assess the impact of macroeconomic variables on NBFIs' profitability in Jamaica will also be examined.

\subsection{Data}

In line with the findings from the literature reviewed and the research problem 


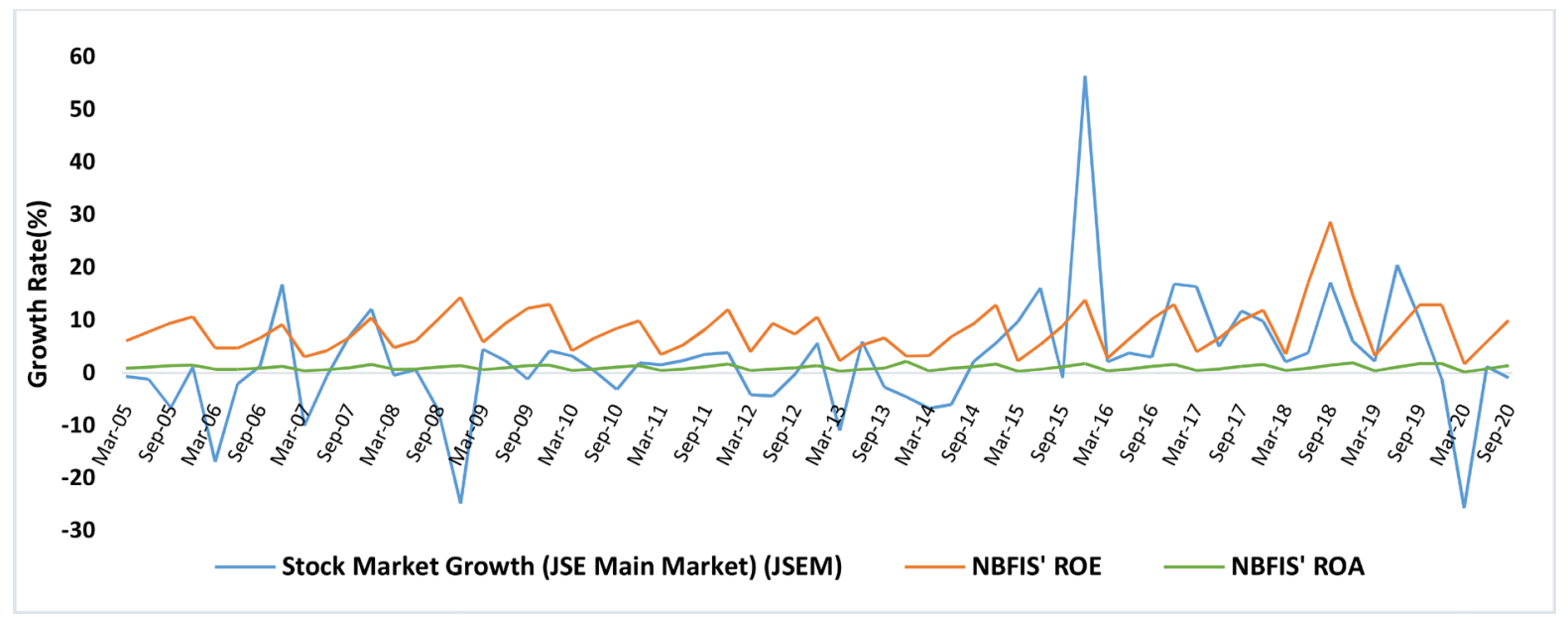

Figure 7. JSEM, ROA and ROE.

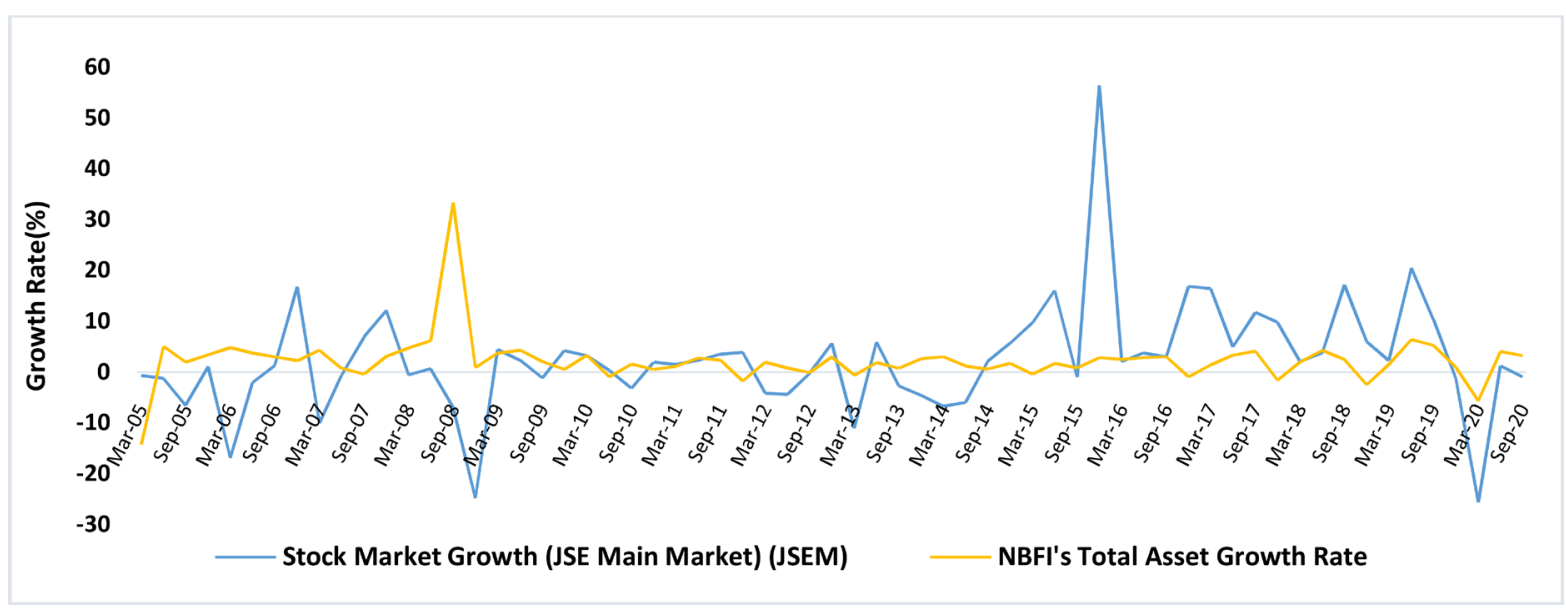

Figure 8. JSEM and TA.

of this study, selected macroeconomic variables were employed to assess NBFIs profitability in Jamaica for the analysis. The data collection used for estimation is an unbalanced panel of quarterly observations for NBFIs: Securities firms, Insurance companies and Pensions licensees from 2005Q1 to 2020Q3.

For measurement of NBFIs performance, return on assets (ROA), return on equity (ROE) and total asset growth (TA) were used for this study. GDP performance was used to measure economic growth. To avoid the issue of bias due to excluded variables, other macroeconomics variables were included such as GOJ bond yields (GBY), Interest rates (IR), stock market growth (JSEM), and unemployment rate (UR). These variables were defined in Table 1.

The profitability metrics of the NBFIs were used as the dependent variables in this analysis, while macroeconomic variables are regressors. Table 2 displays the descriptive statistics of the variables.

\subsection{Unit Root Test}

The first step in the ARDL method was to investigate the stationarity property of 
Table 1. Variable measurement and sources.

\begin{tabular}{|c|c|c|}
\hline Variable & Measure & $\begin{array}{l}\text { Expected } \\
\text { Result }\end{array}$ \\
\hline & Dependent variable & \\
\hline Return on assets (ROA ) & Net income after tax as percentage of total assets (\%) & \\
\hline Return on equity (ROE) & $\begin{array}{c}\text { Net income after tax as percentage of shareholders' } \\
\text { equity (\%) }\end{array}$ & \\
\hline \multirow[t]{2}{*}{ Total Asset Growth (TA) } & $\begin{array}{c}\text { The percentage } \\
\text { change in total assets from current quarter } t \text { - } \\
2 \text { to previous quarter } t-1 \text { minus } 1\end{array}$ & \\
\hline & Independent variable & \\
\hline \multirow[t]{2}{*}{ Real GDP Growth (RGDP) } & $\begin{array}{l}\text { It is a measure of total economic activity/performance } \\
\text { within an economy. The economic growth is measured } \\
\text { as the quarterly change in real Jamaican GDP }\end{array}$ & $+/-$ \\
\hline & Control Variables & \\
\hline Bond Yields (GBY) & $\begin{array}{l}\text { Bond Yields are represented } \\
\text { by the } 1 \text { year GOJ Bond Yields }\end{array}$ & $+1-$ \\
\hline Interest rate (IR) & $\begin{array}{l}\text { Interest rates are represented } \\
\text { by the } 180 \text {-day GOJ Treasury bill rate }\end{array}$ & $+1-$ \\
\hline $\begin{array}{l}\text { Stock Market Growth } \\
\text { (Changes in Main Index) } \\
\text { (JSEM) }\end{array}$ & $\begin{array}{l}\text { Growth was measured by using the daily returns of three } \\
\text { months and finding the average returns for the quarter. }\end{array}$ & $+1-$ \\
\hline Unemployment Rate (UR) & $\begin{array}{l}\text { The number of unemployed as a percentage of the labor } \\
\text { force (the sum of the employed and unemployed) }\end{array}$ & $+1-$ \\
\hline
\end{tabular}

Table 2. Descriptive statistic.

\begin{tabular}{ccccc}
\hline & MEAN & MAXIMUM & MINIMUM & STD.DEV \\
\hline ROA & 1.03 & 2.20 & 0.20 & 0.47 \\
ROE & 8.17 & 28.70 & 1.70 & 4.51 \\
TA & 2.25 & 33.4 & -14.23 & 4.96 \\
GBY & 9.52 & 25.08 & 2.65 & 5.20 \\
RGDP & -0.04 & 6.25 & -15.80 & 3.00 \\
IR & 8.67 & 23.05 & 1.41 & 5.05 \\
JSEM & 2.50 & 56.44 & -25.63 & 11.06 \\
UR & 11.39 & 16.3 & 0 & 2.68 \\
\hline
\end{tabular}

the variables used in the analysis. This was to ensure that none of the variables examined was of order 2, so as not to breach Pesaran et al., (2001)'s underlying assumptions of an ARDL model. Meanwhile, the standard unit root test, according to Zivot and Andrews (1992), such as the augmented Dickey-Fuller (ADF) and Phillips-Peron (PP) tests were found to be skewed towards the inability to reject the null unit root hypothesis in a situation where there was a structural break. Zivot and Andrews (1992) argued that the traditional unit root 
tests, with the presence of structural break, were efficient in the time series, but concluded that if the variable was the first-difference stationary, ADF and PP might not be able to make it known.

Peron's (1989) theory was expanded by Zivot and Andrews (1992) to allow for structural improvements at a time unknown. The following null hypothesis for the series $y_{t}$ in the model was considered in their analysis:

$$
y_{t}=\alpha+y_{t-1}+\varepsilon_{t}
$$

Zivot and Andrews (1992) believed that with the null hypothesis in this form, the $\mathrm{DT}_{\mathrm{B}}$ dummy variable was not needed. While the alternative hypothesis stated that a non-unit root series pattern with a potential structural break could occur at an unknown point in time could represent $y$, as presented in Equations (2)-(4):

$$
\begin{gathered}
y_{t}=\alpha^{a}+\theta^{a} D U_{t}(T b)+\beta^{a} t+\pi^{a} y_{t-1}+\sum_{j=1}^{k} \sigma j^{a} \Delta_{y t-j}+e_{t} \\
y_{t}=\alpha^{b}+\beta t+\gamma^{b} D T_{t}(T b)+\pi^{b} y_{t-1}+\sum_{j=1}^{k} \sigma j^{b} \Delta_{y t-j}+e_{t} \\
y_{t}=\alpha^{c}+\theta^{c} D U_{t}(T B)+\beta^{c} t+\mu^{c} D U_{t}(T b)+\pi^{c} y_{t-1}+\sum_{j=1}^{k} \sigma j^{c} \Delta_{y t-j}+e_{t}
\end{gathered}
$$

In the Equations (2)-(4), $D U_{t}(T b)=1$ if $t>T_{B}, 0$ otherwise, and $D T_{t}(T b)=t-$ $T_{B}$ if $t>T_{B}$. The $\mathrm{k}$ on the left side was included to remove possible nuisance-parameter dependencies in the limit distributions of the test statistic which was as a result of the temporal dependence in the residuals.

\subsection{ARDL Approach}

The ARDL approach included evaluating the conditional error corrected version of the specification for the variables in the study model, in accordance with $\mathrm{Pe}$ saran and Shin (2002). The general ARDL $\left(p, q_{1}, q_{2}, \ldots, q_{k}\right)$ was specified as:

$$
Y_{t}=\gamma_{01}+\sum_{i=1}^{p} \delta Y_{t-1}+\sum_{i=0}^{q} \beta_{i} X_{t-I}+\varepsilon_{i t}
$$

where $Y_{t}$ was a dependent variable and could be a vector variable in $\left(X_{t}^{\prime}\right)$, it was permitted to be purely $\mathrm{I}(0)$ or I(1) or cointegrated; $\beta$ and $\delta$ were coefficients; $\gamma$ was the constant; $i=1, \cdots, k ; p, q$ were optimal lag orders; $\varepsilon_{i t}$ was a vector of the error terms, i.e. unobservable zero means white noise (serially correlated or independent).

In estimating long-run relationships, two steps were involved in the ARDL method. First, it was important to analyse whether co-integration among the variables in the model occurs. This was achieved with the bound test for co-integration, where the hypothesis was defined as followed: $H_{0}: b_{1 i}=b_{2 i}=b_{n}=0$, and the alternative was stated as $H_{1}: b_{1 i} \neq b_{2 i} \neq b_{3 n} \neq 0$ (where $i=1,2, n$ ). There was a failure to reject the null hypothesis if the F-statistic was lower than the upper I(1) bound. But if the F-statistics was greater than the upper I(1) bound, the null hypothesis was accepted which concluded that there was a presence of co-integration among the variable. If the co-integration was established in the model, the model could be re-written from Equation (4) above as: 


$$
Y_{t}=\gamma_{o i}+\sum_{i=1}^{p} \delta_{i} Y_{t-i}+\sum_{i=0}^{q} \beta_{i} X_{t-i}+\lambda E C T_{t-1} \varepsilon_{i t}
$$

where $\lambda=$ speed of adjustment, $E C T=$ the error correction term.

The ARDL techniques were used in the analysis, in accordance with Pesaran et al. (2001), to estimate the existence of co-integration among the variables. As for the three models in the analysis, from Equation (4) the equation was re-written as:

$$
\begin{aligned}
\Delta R O A_{t}= & \Delta R O A_{t}+\alpha_{01}+b_{11} R O A_{t-i}+b_{21} \ln G B Y_{t-i}+b_{31} \ln R G D P_{t-I} \\
& +b_{41} \ln I R_{t-I}+b_{51} \ln J S E M_{t-I}+b_{61} \ln U R_{t-I}+\sum_{i=1}^{p} a_{1 i} \Delta R O A_{t-I} \\
& +\sum_{i=1}^{q} a_{21} \Delta \ln G B Y_{t-i}+\sum_{i=1}^{q} a_{31} \Delta \ln R G D P_{t-I}+\sum_{i=1}^{q} a_{41} \Delta \ln I R_{t-I} \\
& +\sum_{i=1}^{q} a_{51} \Delta \ln J S E M_{t-I}+\sum_{i=1}^{q} a_{61} \Delta \ln U R_{t-I}+e_{1 t} \\
\Delta R O E_{t}= & \Delta R O E_{t}+\alpha_{01}+b_{11} R O E_{t-i}+b_{21} \ln G B Y_{t-i}+b_{31} \ln R G D P_{t-I} \\
& +b_{41} \ln I R_{t-I}+b_{51} \ln J S E M_{t-I}+b_{61} \ln U R_{t-I}+\sum_{i=1}^{p} a_{1 i} \Delta R O E_{t-I} \\
& +\sum_{i=1}^{q} a_{21} \Delta \ln G B Y_{t-i}+\sum_{i=1}^{q} a_{31} \Delta \ln R G D P_{t-I}+\sum_{i=1}^{q} a_{41} \Delta \ln I R_{t-I} \\
& +\sum_{i=1}^{q} a_{51} \Delta \ln J S E M_{t-I}+\sum_{i=1}^{q} a_{61} \Delta \ln U R_{t-I}+e_{1 t} \\
\Delta T A_{t}= & \Delta T A_{t}+\alpha_{01}+b_{11} T A_{t-i}+b_{21} \ln G B Y_{t-i}+b_{31} \ln R G D P_{t-I} \\
& +b_{41} \ln I R_{t-I}+b_{51} \ln J S E M_{t-I}+b_{61} \ln U R_{t-I}+\sum_{i=1}^{p} a_{1 i} \Delta T A_{t-I} \\
& +\sum_{i=1}^{q} a_{21} \Delta \ln G B Y_{t-i}+\sum_{i=1}^{q} a_{31} \Delta \ln R G D P_{t-I}+\sum_{i=1}^{q} a_{41} \Delta \ln I R_{t-I} \\
& +\sum_{i=1}^{q} a_{51} \Delta \ln J S E M_{t-I}+\sum_{i=1}^{q} a_{61} \Delta \ln U R_{t-I}+e_{1 t}
\end{aligned}
$$

In addition, from Equation (8), $t$ was the time trend, while $e$ was the error term in the models. The first parts of this equation with $b_{11}-b_{61}$ were the short-run dynamic coefficients of the model's adjustment long-run equilibrium, while the second parts with $\alpha_{21}-\alpha_{61}$ were the long-run parameters. The null hypothesis in Equation (8) was $b_{11}=b_{61}=0$, which indicated no co-integration, and the alternative hypothesis was $b_{11} \neq b_{61} \neq 0$.

Based on Pesaran et al., (2001), and in line with Equation (5), the error correction model (ECM) representation for the study was specified as:

$$
\begin{aligned}
\Delta R O A_{t}= & \Delta R O A_{t}+\alpha_{01}+\sum_{i=1}^{p} a_{1 i} \Delta R O A_{t-I}+\sum_{i=1}^{q} a_{21} \Delta \ln G B Y_{t-i} \\
& +\sum_{i=1}^{q} a_{31} \Delta \ln R G D P_{t-I}+\sum_{i=1}^{q} a_{41} \Delta \ln I R_{t-I} \\
& +\sum_{i=1}^{q} a_{51} \Delta \ln J S E M_{t-I}+\sum_{i=1}^{q} a_{61} \Delta \ln U R_{t-I}+\lambda E C T_{t-I}+e_{t} \\
\Delta R O E_{t}= & \Delta R O E_{t}+\alpha_{01}+\sum_{i=1}^{p} a_{1 i} \Delta R O E_{t-I}+\sum_{i=1}^{q} a_{21} \Delta \ln G B Y_{t-i} \\
& +\sum_{i=1}^{q} a_{31} \Delta \ln R G D P_{t-I}+\sum_{i=1}^{q} a_{41} \Delta \ln I R_{t-I} \\
& +\sum_{i=1}^{q} a_{51} \Delta \ln J S E M_{t-I}+\sum_{i=1}^{q} a_{61} \Delta \ln U R_{t-I}+\lambda E C T_{t-I}+e_{1 t} \\
\Delta T A_{t}= & \Delta T A_{t}+\alpha_{01}+\sum_{i=1}^{p} a_{1 i} \Delta T A_{t-I}+\sum_{i=1}^{q} a_{21} \Delta \ln G B Y_{t-i} \\
& +\sum_{i=1}^{q} a_{31} \Delta \ln R G D P_{t-I}+\sum_{i=1}^{q} a_{41} \Delta \ln I R_{t-I} \\
& +\sum_{i=1}^{q} a_{51} \Delta \ln J S E M_{t-I}+\sum_{i=1}^{q} a_{61} \Delta \ln U R_{t-I}+\lambda E C T_{t-I}+e_{1 t}
\end{aligned}
$$


The fitness of the ARDL model, diagnostic and stability test was performed to ensure the robustness of the analysis. In the diagnostic test, the model investigated serial association and heteroskedasticity problems. The total number of CUSUM has been used to test the model's stability.

\section{Results and Discussion}

\subsection{Unit Root Test}

Both the ADF and Zivot-Andrew tests were used to assess the stationarity of the variables. This was used by the author based on the Zivot and Andrew (1992) argument that the standard unit root test was likely to be biased in the event of a structural break.

The analysis, as described in Table 3, revealed that only GBY and IR were stationary in levels, while other variables were found to be stationary when first differenced. The Zivot-Andrew test, as seen in Table 3, indicated that most of the variables assumed to be stationary in levels were generally stationary in levels in the presence of structural break. The application of the two tests supported the validity of Zivot and Andrew's (1992) statement in terms of bias appearing in the event of a structural break. The two unit root tests used in the analysis, however, showed that all the variables in the model were of a mixed order of integration $(0 \& 1)$. Thus, the ARDL approach was safe to start with.

\subsection{Co-Integration Test}

The ARDL system included a prior test for the co-integration of the variables in the model, in line with Pesaran et al., (2001). Thus, the test was carried out using both the Johansen co-integration test and the co-integration binding test. To analyze each model's sensitivity to co-integration between the dependent and regressor variables, the two tests were combined.

Table 3. Unit root test.

\begin{tabular}{|c|c|c|c|c|c|}
\hline \multirow{2}{*}{ VARIABLE } & \multicolumn{2}{|c|}{$\begin{array}{c}\text { AUGMENTED } \\
\text { DICKEY-FULLER }\end{array}$} & \multicolumn{3}{|c|}{ ZIVOT-ANDREW } \\
\hline & LEVELS & $1^{\mathrm{ST}}$ DIFF. & LEVELS & $1^{\mathrm{ST}} \mathrm{DIFF}$ & STRUCTURAL BREAK \\
\hline ROA & $-8.791^{\star * *}$ & & $-12.17^{\star * *}$ & & 2012Q3 \\
\hline $\mathrm{ROE}$ & $-6.296^{\star * *}$ & & $-7.38^{\star * *}$ & & 2018Q2 \\
\hline TA & $-8.23^{* * *}$ & & $-8.49^{* * *}$ & & \\
\hline GBY & -1.479 & $-5.135^{\star \star *}$ & -3.05 & $-5.17^{\star * *}$ & 2010Q1 \\
\hline RGDP & $-9.978^{\star * *}$ & & $-7.673^{* * *}$ & & 2018Q2 \\
\hline IR & -0.686 & $-4.323^{\star * \star}$ & -3.457 & $-4.404^{\star}$ & 2010Q1 \\
\hline JSEM & $-6.873^{\star * *}$ & & $-7.871^{* \star *}$ & & 2015Q4 \\
\hline UR & $-4.144^{\star * *}$ & & $-4.45^{\star *}$ & & 2011Q3 \\
\hline
\end{tabular}

${ }^{*}, * *$ and ${ }^{* * *}$ stand for $10 \%, 5 \%$, and $1 \%$ levels of significance, respectively. 
As seen in Table 4, the outcome of the Johansen co-integration test revealed that the first model, which was the ROA as a dependent variable and other variables as independent variables, had 5 numbers of co-integration equations. This was due to the trace statistics that have been shown to be significant for each hypothesis, and as such, the null hypothesis was rejected. Besides this, the co-integration bound testing result for Model 1 indicated no co-integration. This was attributed to the non-significance of the f-statistic. Based on the statistics, the numbers were found to be smaller than the upper bound I(1) at the significance level of $10 \%, 5 \%$ and $1 \%$.

As for Model 2, the Johansen co-integration test revealed that there was co-integration between the ROE and independent variables in the results as presented in Table 4. The co-integration was also defined by the bound co-integration measure that showed an f-statistic (4.94) that was found to be higher at a $5 \%$ significance level than the upper bound I(1).

Correspondingly, the Johansen and bound co-integration test indicated a co-integration between the TA as a dependent variable and the independent variables GBY, RGDP, IR, JSEM, and UR. For the bound test, the f-statistic (8.35) was found to be higher at the $1 \%$ significance level than the $\mathrm{I}(1)$ upper bound, thereby rejecting the null hypothesis of no co-integration.

\subsection{Short and Long-Run Causal Relationship}

Due to the co-integration of dependent and independent variables, equations 9, 10 and 11 were determined for Model 1, 2, \& 3 and the results were summarized and presented in Table 5. The findings presented in Table 5 for Model 1 revealed that there was a long-run causal relationship between RGDP, UR and ROA. The findings also indicated that RGDP had a long-run effect on ROA and that the effect was significantly positive at a $5 \%$ confidence level. Comparably,

Table 4. Co-integration test.

\begin{tabular}{|c|c|c|c|}
\hline HYPOTHESIZED NO. OF & $\begin{array}{l}\text { ROA, GBY, RGDP, } \\
\text { IR, JSEM, UR }\end{array}$ & $\begin{array}{l}\text { ROE, GBY, RGDP, } \\
\text { IR, JSEM, UR }\end{array}$ & $\begin{array}{l}\text { TA, GBY, RGDP, } \\
\text { IR, JSEM, UR }\end{array}$ \\
\hline $\mathrm{CE}(\mathrm{S})$ & TRACE STATISTICS & $\begin{array}{c}\text { TRACE } \\
\text { STATISTICS }\end{array}$ & $\begin{array}{c}\text { TRACE } \\
\text { STATISTICS }\end{array}$ \\
\hline $\mathrm{NONE}^{*}$ & 153.82 & 141.47 & 183.61 \\
\hline $\operatorname{AT} \operatorname{MOST} 1^{*}$ & $87.08^{\star * *}$ & 74.636 & 96.14 \\
\hline $\operatorname{AT} \operatorname{MOST} 2^{*}$ & $58.77^{\star * *}$ & $48.46^{* * *}$ & $56.78^{* * *}$ \\
\hline $\operatorname{AT} \operatorname{MOST} 3^{*}$ & $32.31^{\star * *}$ & $28.54^{\star * *}$ & $28.67^{\star * *}$ \\
\hline $\mathrm{AT} \operatorname{MOST} 4^{*}$ & $16.45^{\star * *}$ & $12.75^{\star *}$ & $12.99^{* * *}$ \\
\hline $\operatorname{AT} \operatorname{MOST} 5^{*}$ & $3.44^{* *}$ & $4.06^{* *}$ & $3.27^{\star *}$ \\
\hline $\begin{array}{c}\text { BOUNDS } \\
\text { TEST(F-STATISTIC) }\end{array}$ & 1.23 & $4.94^{* * *}$ & $8.35^{* * *}$ \\
\hline
\end{tabular}

${ }^{*},{ }^{*}$, and ${ }^{* * *}$ stand for $10 \%, 5 \%$, and $1 \%$ levels of significance, respectively. 
UR was found to have a major effect on the long-run profitability of NBFIs' ROA. Meanwhile, the importance of GBY, IR, and JSEM could not be identified. In the short-run estimates, however, minimal short-run causal relationships among variables could be identified with ROA. As seen in Table 5, the model error correction term (ECT) dictated that the coefficient was negative and significant at a confidence level of $10 \%$. This implied that the model will converge back to the equilibrium at the speed of $66 \%$ in the event of a shock.

The Model 2 assessment as provided in Table 5 showed that four variables were considered to have a major long-run causal association with ROE: GBY, UR, IR, and JSEM. Meanwhile, because of the non-significance of the RGDP coefficient, the long-run causal relationship between RGDP and ROE could not be identified. However, in the short-run estimates, all the variables were found not to be significant. This outcome means that the ROE of the NBFIs was less vulnerable in the short-run to RGDP, UR, IR, GBY, and JSEM. In addition, as presented in Table 5, the ECT for Model 2 indicated that the coefficient was negative and statistically significant. This was anticipated since, in the event of disequilibrium, the negative coefficient and its significance would guarantee convergence back to the model's equilibrium. The ECT further revealed that the model would have a sluggish rate of change of around $47 \%$ back to equilibrium in the event of a shock. In comparison, a consistent long-run relationship was suggested by the significance of the ECT and implied a long-run co-integration between certain independent variables that were significant and the dependent variable.

The results of Model 3, which showed a log-run causal relationship between TA and GBY, RGDP, IR, and JSEM were also provided in Table 5. However, the short-run causal relationship between all variables and TA could not be established due to the lack of significance of coefficients. Furthermore, Table 5 indicated that the ECT coefficient was negative (-) and statistically significant at the $1 \%$ confidence level. This means that the model would return to equilibrium at a pace of $81 \%$ in the event of a shock. The negative and significance of the ECT coefficient also confirmed the presence of a consistent long-run relation between the dependence variable (TA) and the independent variables (RGDP, UR, IR, JSEM, and GBY) which have been shown to have significant coefficients.

Moreover, Table 5 indicated that the Durbin-Watson (DW) ${ }^{2}$ coefficients for the ROA and ROE were less than 2.0 and as such, the null hypothesis of no autocorrelation was rejected at a $5 \%$ significant level. This indicated that there was a positive autocorrelation detected in the sample. TA's DW coefficient, however, was close to 2 , being the middle of the range, which indicated there was less autocorrelation detected in the sample.

The diagnostic test was carried out on the three models using the Breush-Godfrey ${ }^{2}$ Durbin-Watson tests for autocorrelation in residuals from a regression analysis. The test statistic ranges between 0 to 4 . A value of 2 indicates that there is less autocorrelation. Value nearing 0 (i.e., below 2) indicates positive autocorrelation and a value towards 4 (i.e., over 2) indicates negative autocorrelation. 
serial correlation LM test serial correlation issue, the Breusch-Pagan-Godfrey heteroskedasticity test and the cumulative sum of recursive residuals (CUSUM) to assess the stability of the models to ensure the robustness of the estimate. Table 5 presented the outcomes of the tests. It revealed that for the serial correlation test, the three models had p-values that were higher than 0.05 . Therefore, the study failed to reject the null hypothesis that there is no serial correlation. Likewise, the heteroskedasticity test for the models revealed that the p-values $(58,58$, and 38.40) were all higher than 0.05 . Thus, the study failed to reject the null hypothesis of homoscedasticity.

Finally, the findings of the stability test were presented in Table 5 and Figures 9-11. The findings shown in Figures 9-11 demonstrated that the CUSUM value lies with the $5 \%$ significance boundary. This implied the stability of the models.

Table 5. Long-run causal relationship.

\begin{tabular}{cccc}
\hline DEPENDENT VARIABLE & ROA $(\mathbf{4}, \mathbf{0}, \mathbf{0}, \mathbf{2 , 1 , 2 )}$ & ROE $(1,3,0,0,0,0)$ & TA $(1,0,0,0,0,0)$ \\
\hline LONG-RUN & & & \\
GBY & -0.16 & $-1.16^{* *}$ & $1.00^{* *}$ \\
RGDP & $-0.02^{* *}$ & 1.76 & $-0.41^{* *}$ \\
IR & 0.23 & $1.12^{* *}$ & $-0.82^{* *}$ \\
JSEM & -0.02 & $0.17^{* *}$ & $0.04^{* *}$ \\
UR & $-0.01^{* *}$ & $0.20^{* *}$ & $-0.11^{* *}$ \\
ECT & $-0.66^{* *}$ & $-0.47^{* *}$ & $-0.81^{* * *}$ \\
Durbin-Watson & 1.20 & 1.76 & 2.03 \\
SER. CORR $\left(\mathrm{X}^{2}\right)$ & $12.709^{* * *}$ & $3.93^{* *}$ & 0.43 \\
HETERO. & 58 & 58 & 38.40 \\
STABILITY & STABLE & STABLE & STABLE
\end{tabular}

${ }^{*},{ }^{* *}$, and ${ }^{* *}$ stand for $10 \%, 5 \%$, and $1 \%$ levels of significance, respectively.

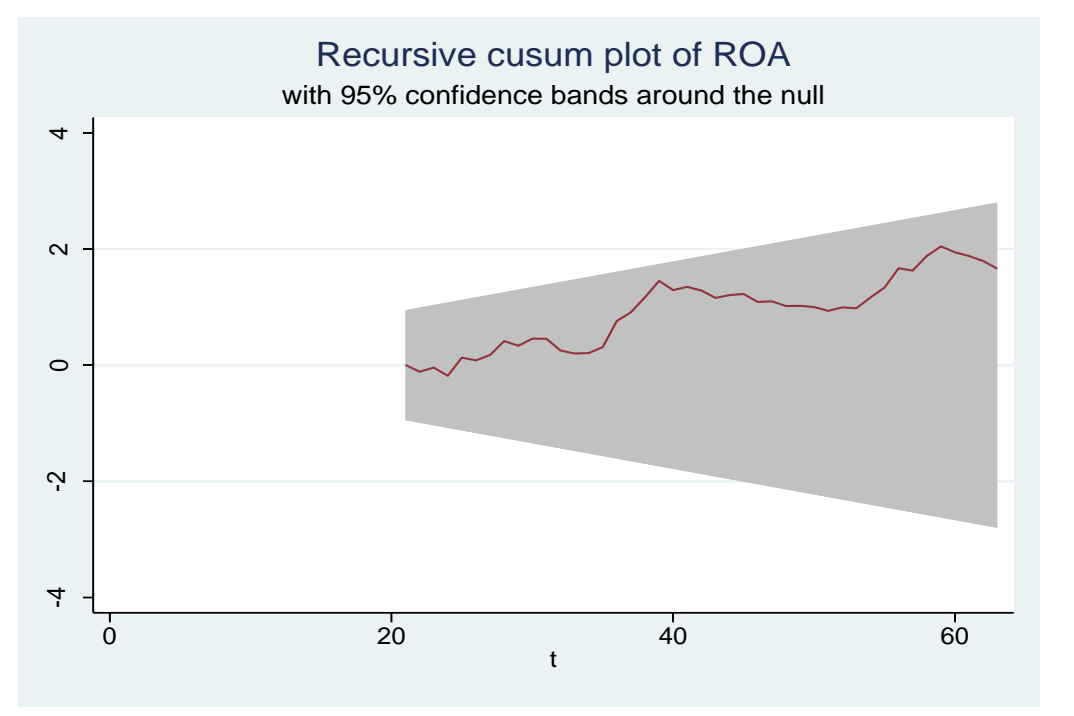

Figure 9. Model $1(\mathrm{ROA}=$ Dependent Variable $)$. 


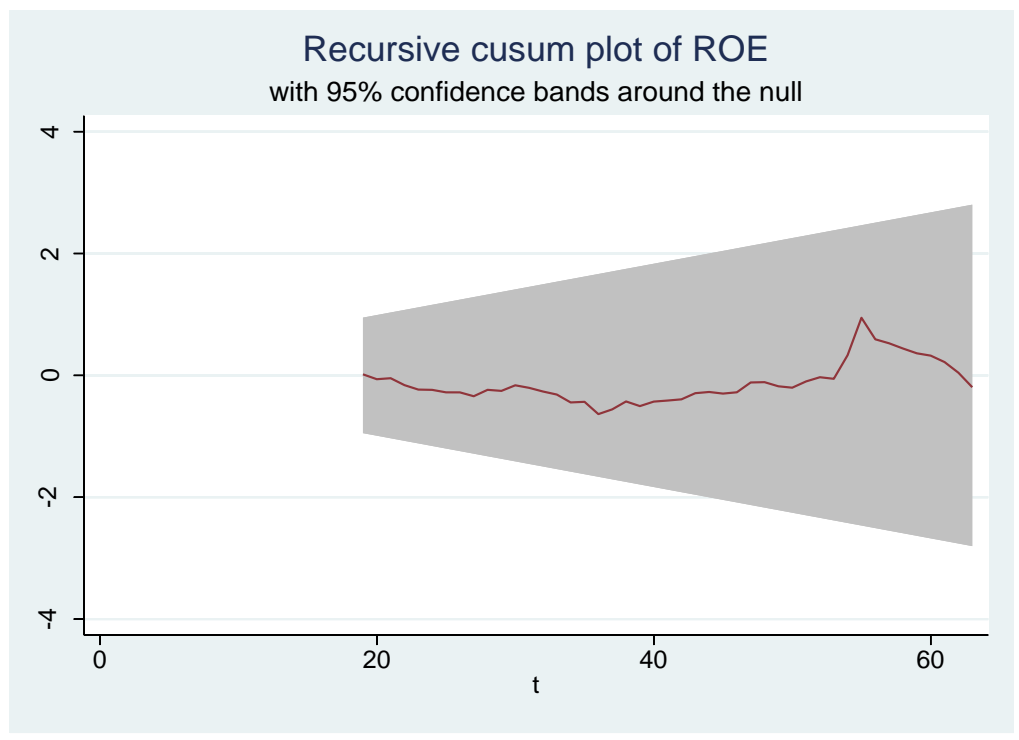

Figure 10. Model $2(\mathrm{ROE}=$ Dependent Variable $)$.

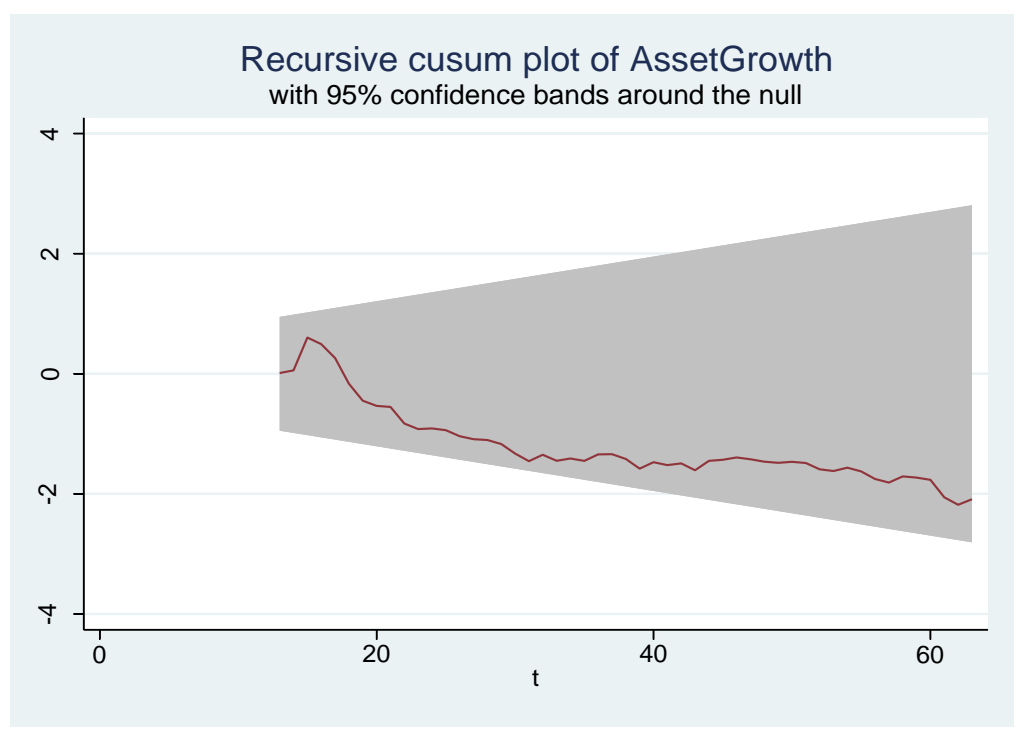

Figure 11. Model $3(\mathrm{TA}=$ Dependent Variable $)$.

\subsection{Discussion}

In this study, three models were tested in which the profitability metrics of NBFIs (ROA, ROE, \& TA) were provided as a dependent variable.

The role of RGDP in the long-run causal relationship with ROA, as seen in Table 5, in Model 1, suggested that Jamaica's economic growth has negatively affected the NBFIs' ROA. The outcome was consistent with several previous research (Alper \& Anbar, 2011; Banerjee \& Majumdar, 2014) that have performed related studies on the effect of GDP on the ROA of banks and have observed negative results in their separate studies. The negative effect of RGDP on NBFIs' asset prices in Jamaica implied that a higher GDP would lead to stronger growth in assets relative to profits and so the ROA may decline. This further indicates 
that firms in Jamaica have actively taken aggressive measures to extend their business models as a consequence of Jamaica's economic growth thus creating more income in the economy, stronger demand for bonds and lower yields.

Additionally, the negative significance of the JSEM, in the long-run, on the NBFIs' ROA in Jamaica suggests that the rise and decline in share prices affected the NBFIs' market capitalization and, therefore, its market valuation. It also influences decisions on the issuing of shares and NBFIs' capital costs ${ }^{3}$ thus, impacting the equity investors in both personal and retirement portfolios. Similarly, the negative impact of GBY, in the long-run, on NBFIs' ROA means that NBFIs are taking on accumulated government debt that could have a negative influence on the NBFI's viability. Simply put, any funding of government debt through government bonds would impede the NBFIs market, particularly if government debt continues to grow as a percentage of GDP.

Model 2 was calculated by replacing the dependent variable (ROA) in Model 1 with ROE to analyze the effect of the model's macroeconomic variables on this profitability measure for the NBFIS. The outcome shown in Table 5 revealed that while GBY has been found to have a significant negative effect on the ROE of NBFIs, RGDP, IR, JSEM and UR were found to have a positive impact on NBFI's ROE.

The positive effect of RGDP on the ROE observed in this analysis indicates that higher economic growth typically enables NBFIs to lend more and encourages them to charge higher margins while improving their asset quality. This is because businesses have more favourable net present value initiatives that they would like to pursue during boom seasons thus, giving rise to their appetite for credit as they need funds to conduct those projects. The growth in credit demand translates to higher interest margins for financial institutions, which in turn leads to greater profitability for NBFIs.

Additionally, the analysis found a positive relationship between IR and the NBFI performance (ROE). This indicates that NBFIs appear to do best in periods of increasing interest rates. The NBFIs market is usually supported rather than hampered in periods of rising interest rates. This is because a majority of the revenue earned by these firms derives from interest income. As a result, higher interest rates imply higher interest income for NBFIs and therefore an improvement in profitability which in turn affects asset prices. As it relates to the negative effect of the GBY on the NBFI's ROE found in this analysis, it suggests that the profitability of NBFIs in Jamaica is vulnerable to government debt and it also may have a potential impact on fair value losses when interest rates increase.

Total asset growth (TA) was the dependent variable for model 3, with five macroeconomic variables (GBY, RGDP, IR, JSEM, \& UR) examined. RGDP, IR and UR were respectively found to have a long-run significant impact on TA. GBY and JSEM, however, had a positive long-run causal impact on TA. The im-

${ }^{3}$ The averaging costs of a company debt and equity capital. 
plication of the significant positive findings of GBY and JSEM effect on the NBFIs' TA, and by their profitability, is that NBFIs would anticipate that as bond yields rise, buyers will move their capital from the stock market, assuming that higher borrowing costs will adversely impact the balance sheet resulting in a devaluation of the stock price thus, impacting assets growth.

\section{Conclusion}

This research analyzed how the asset positions and financial performance of the regulated sectors (Insurance, Securities and Pension) NBFIs respond to the impact of different macroeconomic variables using the ARDL bounds testing approach to co-integration over the 2005Q1 to 2020Q3 period. Thus, in the case of Jamaica, government bond yield, stock market changes, economic growth, interest rates, and unemployment rate have been found to have a significant impact on the sustainability of the profitability of NBFIs.

The presence of a stable long-run relationship is further demonstrated by the negative and significant coefficients of the error correction terms (ECT). The analysis also used the stability measurement of the CUSUM and CUSUM squares. The test does not confirm any proof of any significant structural instability of the long-run coefficients of the output function. The estimation results indicate that both NBFIs and the other variables used in the model play a significant role in understanding the variations in the long-run in the real GDP in Jamaica.

One significant contribution of the study is that while empirical studies are scarce on the impact of macroeconomic variables on NBFIs' profits, as the majority are on bank profitability in developed countries and few developing countries, this study offers an empirical perspective to resolve the absence of literature on the influence of macroeconomic variables on the sustainability of Jamaica's NBFIs profitability.

The error correction term that was found to be important is another insightful contribution of the research, which implies that in case of a shock to the system, the model will converge back to equilibrium.

\section{Policy Recommendation}

As far as policy recommendations are concerned, the findings suggest that NBFIs are one of the main components of the financial system from which financial capital is efficiently channelled from savers to investors in the economy. Therefore, it is necessary for the competent authorities to deeply analyze the processes by which financial services are provided more efficiently by the NBFIs to facilitate long-term economic development. This will allow the authorities concerned to develop prudent strategies for their further advancement and thus, achieve sustained economic growth in Jamaica over the long-term.

The growth of NBFIs can be a significant catalyst for fostering economic growth, especially by providing long-term funding for profitable investment activities where the financing activities of the traditional banking system are most- 
ly constrained. Besides, the growth of NBFIs will also encourage the growth of small and medium-sized enterprises with restricted opportunities to fulfil their financial needs by joining the stock market as well as through the commercial banking sector.

Moreover, NBFI managers must take these factors into account in their management policies because they have the potential to affect their performance significantly. Besides, regulatory authorities should take into account the effect of the risk-taking practices of NBFIs on their performance and conduct better supervision and implementation of regulations. These activities would go a long way towards enhancing the efficiency of the NBFI industry, which will help to improve the country's financial system.

\section{Conflicts of Interest}

The author declares no conflicts of interest regarding the publication of this paper.

\section{References}

Aihie, J. A., \& Eburajolo, C. O. (2018). Impact Macroeconomic Variables on the Growth of Finance Houses in Nigeria. West African Social and Management Science Review, 8 , 41-49. http://oer.biu.edu.ng/wp-content/uploads/2019/05/WASMSRv8 4.pdf

Alper, D., \& Anbar, A. (2011). Bank Specific and Macroeconomic Determinants of Commercial Bank Profitability: Empirical Evidence from Turkey. Business and Economics Research Journal, 2, 139-152

Athanasoglou, P., Brissimis, S., \& Delis, M. (2008). Bank-Specific, Industry-Specific and Macroeconomic Determinants of Bank Profitability. Journal of International Financial Markets, Institutions and Money, 18, 121-136. https://doi.org/10.1016/j.intfin.2006.07.001

Banerjee, R., \& Majumdar, S. (2014). Profitability Determinants of Commercial Banks in UAE-A Sure Model Approach. Third Asian Business Research Conference, Abu Dhabi, 15-16 September 2014, 74.

Bangladesh Bank's Financial Stability Report (2010). https://www.bb.org.bd/pub/annual/fsr/final stability report2010.pdf

Bernoth, K., \& Pick, A. (2009). Forecasting the Fragility of the Banking and Insurance Sector. DNB Working Papers 202, Netherlands Central Bank, Research Department.

Bikker, J. A., \& Hu, H. (2002). Cyclical Patterns in Profits, Provisioning and Lending of Banks and Procyclicality of the New Basel Capital Requirements. PSL Quarterly Review, 55, 143-175.

https://citeseerx.ist.psu.edu/viewdoc/download?doi=10.1.1.476.1691\&rep=rep1\&type= pdf

Bilal, M., Saeed, A., Gull, A. A., \& Akram, T. (2013). Influence of Bank Specific and Macroeconomic Factors on Profitability of Commercial Banks: A Case Study of Pakistan. Research Journal of Finance and Accounting, 4, 117-126.

Demirguc-Kunt, A., \& Huizinga, H. (1999). Determinants of Commercial Bank Interest Margins and Profitability: Some International Evidence. The World Bank Economic Review, 13, 379-408. https://doi.org/10.1093/wber/13.2.379 
Gul, S., Irshad, F., \& Zaman, K. (2011). Factors Affecting Bank Profitability in Pakistan. Romanian Economic Journal, 14, 61-87.

https://www.researchgate.net/publication/227487619_Factors Affecting_Bank Profita bility in Pakistan

Islam, M. A., \& Osman, J. B. (2011). Development Impact of Non-Bank Financial Intermediaries on Economic Growth in Malaysia: An Empirical Investigation. International Journal of Business and Social Science, 2, 187-198.

Islatince, N. (2015). Analysis of the Factors That Determine the Profitability of the Deposit Banks in Turkey. Journal of Applied Finance and Banking, 5, 175.

Johannes, S. (2015). The Macroeconomic Determinants of Profitability among Commercial Banks in Namibia. Journal of Emerging Issues in Economics, Finance and Banking, 4, 1414-1431.

Kanwal, S., \& Nadeem, M. (2013). The Impact of Macroeconomic Variables on the Profitability of Listed Commercial Banks in Pakistan. European Journal of Business and Social Sciences, 2, 186-201.

Kosmidou, K., Tanna, S., \& Pasiouras, F. (2008). Determinants of Profitability of Domestic UK Commercial Banks: Panel Evidence from the Period 1995-2002. Economics, Finance and Accounting Applied Research Working Paper Series No. RP08-4, Coventry: Coventry University.

Mazumder, M. A. (2015). Stimulants of Profitability of Non-Bank Financial Institutions: Evidence from Bangladesh. International Journal of Business and Management Review, 3, 32-41.

Pan, Q. H., \& Pan, M. L. (2014). The Impact of Macro Factors on the Profitability of China's Commercial Banks in the Decade after WTO Accession. Open Journal of Social Sciences, 2, 64-69. https://doi.org/10.4236/jss.2014.29011

Pesaran, M. H., \& Shin, Y. (2002). Long-Run Structural Modelling. Econometric Reviews, 21, 49-87. https://doi.org/10.1081/ETC-120008724

Pesaran, M. H., Shin, Y., \& Smith, R. J. (2001). Bounds Testing Approaches to the Analysis of Level Relationships. Journal of Applied Econometrics, 16, 289-326. https://doi.org/10.1002/jae.616

Rabaa, B., \& Younes, B. (2016). The Impact of the Islamic Banks Performances on Economic Growth: Using Panel Data. International Journal of Economics and Finance Studies, 8, 101-111. https://sobiad.org/eJOURNALS/journal IJEF/archieves/IJEF-2016 1/badri.pdf

Siddiqui, S. S. (2012). Capital Structure Determinants of Non-Bank Financial Institutions (NBFIs) in Bangladesh. World Review of Business Research, 5, 60-78.

Simiyu, C. N., \& Ngile, L. (2015). Effect of Macroeconomic Variables on Profitability of Commercial Banks Listed in the Nairobi Securities Exchange. International Journal of Economics, Commerce and Management, 3, 1-16.

Vong, A. P. I., \& Chan, H. S. (2009). Determinants of Bank Profitability in Macao. Working Paper Series, Macau: University of Macau.

https://www.researchgate.net/publication/252081427 Determinants of Bank Profitab ility in Macao

Zivot, E., \& Andrews, W. K. (1992). Further Evidence on the Great Crash, the Oil-Price Shock, and the Unit Root Hypothesis. Journal of Business and Economic Statistics, 10, 251-270. https://doi.org/10.1080/07350015.1992.10509904 